\title{
Nodular and sclerosing gastritis caused by Cylicospirura felineus in a puma (Puma concolor)
}

\author{
Gastrite nodular esclerosante causada por Cylicospirura felineus em onça \\ parda (Puma concolor)
}

\begin{abstract}
Lara Ribeiro de Almeida'; Mirella Lauria D’Elia²; Dyeime Ribeiro de Sousa;
Jéssica de Souza Joaquim; Hudson Andrade Santos'; Bruna Hermine Campos²; Cintia Aparecida de Jesus Pereira1; Danielle Ferreira de Magalhães Soares ${ }^{2}$; Walter dos Santos Lima'; Roselene Ecco ${ }^{3 *}$ (1)
'Laboratório de Helmintologia Veterinária, Departamento de Parasitologia, Instituto de Ciências Biológicas, Universidade Federal de Minas Gerais - UFMG, Belo Horizonte, MG, Brasil
${ }^{2}$ Departamento de Medicina Veterinária Preventiva, Escola de Veterinária, Universidade Federal de Minas Gerais - UFMG, Belo Horizonte, MG, Brasil
${ }^{3}$ Setor de Patologia, Departamento de Clínica e Cirurgia Veterinárias, Escola de Veterinária, Universidade Federal de Minas Gerais UFMG, Belo Horizonte, MG, Brasil
\end{abstract}

How to cite: Almeida LR, D'Elia ML, Sousa DR, Joaquim JS, Santos HA, Campos BH, et al. Nodular and sclerosing gastritis caused by Cylicospirura felineus in a puma (Puma concolor). Braz J Vet Parasito/ 2020;29(2): e023519. https://doi.org/10.1590/S1984-29612020048

\begin{abstract}
An adult male puma (Puma concolor), hit by a car in an urban area, died three days later despite the therapeutic support provided. At necropsy, multiple firm nodules were identified in the gastric mucosa. The nodules were coated by an intact mucosa with a central opening from which reddish and cylindrical nematodes protruded into the lumen. Twenty-seven nematodes were retrieved for morphological and morphometric evaluations. During histopathological examination of the gastric tissue, the adult nematodes appear in longitudinal and transverse sections, surrounded by thick bands of collagen, interspersed with mixed inflammatory infiltrates. The nematodes had an eosinophilic cuticle with caudal serrated projections (bulbar type), coelomyarian musculature, pseudocoelom, and females with uterus containing numerous larvated eggs, characteristics consistent with the Cylicospirura genus. Morphologically, female nematodes had six large tricuspid teeth in the oral cavity and the vulva had an opening anterior to the esophagus-intestinal junction. Male nematodes had five pairs of small papillae near the tip of the tail. These findings were consistent with Cylicospirura felineus. This parasite should be included in the differential diagnosis of nodular gastric wall lesions in wild felids.
\end{abstract}

Keywords: Cylicospirura felineus, taxonomy, morphology, histopathology, wild felids.

\begin{abstract}
Resumo
Uma onça parda (Puma concolor) foi encontrada em uma área urbana após atropelamento e, apesar do suporte terapêutico fornecido, o animal morreu três dias depois. No exame post-mortem, múltiplos nódulos firmes foram identificados na mucosa gástrica. Os nódulos eram revestidos por mucosa intacta com um orifício central, do qual se insinuavam nematódeos cilíndricos e avermelhados. Vinte e sete nematódeos foram recuperados para avaliação morfológica e morfométrica. Na avaliação histopatológica do tecido gástrico, os nematódeos adultos apareceram em cortes longitudinais e transversais, circundados por bandas espessas de colágeno, intercaladas por infiltrado inflamatório misto. Os nematódeos eram constituídos por cutícula eosinofílica, com projeções serrilhadas voltadas caudalmente (do tipo bulbar), musculatura celomiariana, pseudoceloma e, nas fêmeas, útero com numerosos ovos larvados cujos achados foram sugestivos do gênero Cylicospirura. Morfologicamente, a cavidade bucal continha seis grandes dentes trífidos, na fêmea, a abertura da vulva era anterior à junção esôfago intestinal; e os machos tinham cinco pares de pequenas papilas próximas à ponta da cauda. Esses achados foram consistentes com Cylicospirura felineus. Este parasita deve ser incluído no diagnóstico diferencial de lesões nodulares da parede gástrica em felinos selvagens.
\end{abstract}

Palavras-chave: Cylicospirura felineus, taxonomia, morfologia, histopatologia, felídeos selvagens.

Received December 21, 2019. Accepted May 13, 2020.

*Corresponding author: Roselene Ecco. E-mail: ecco@vet.ufmg.br

This is an Open Access article distributed under the terms of the Creative Commons Attribution License, which permits unrestricted use, distribution, and reproduction in any medium, provided the original work is properly cited. 


\section{Introduction}

Puma (Puma concolor Linnaeus, 1771) belongs to the order Carnivora and Felidae family. It is the most widely distributed large terrestrial mammal in the neotropical region, found in southern Canada and spread to the southernmost regions of South America (Wainwright et al., 2010; Vickers et al., 2015). Present in all Brazilian biomes, the puma has great plasticity in adapting to various types of environments with different degrees of disturbance. However, habitat fragmentation and human-wildlife conflicts, caused by increased habitat conversion into crop, livestock, and housing areas are resulting in changes to the patterns of prey communities. Therefore, food availability poses a major threat to the survival of this species in many countries (Conforti \& Azevedo, 2003; Treves \& Karanth, 2003; Dotta \& Verdade, 2011; Vickers et al., 2015).

Cylicospirura felineus is a nematode belonging to the superfamily Spiruroidea, family Spirocercidae, and subfamily Spirocercinae. C. felineus was first described in domestic cats from India as Spirocerca felineus (Chandler, 1925). It was later renamed Cylicospirura felineus when reported in Felis bengalensis (synonym Prionailurus bengalensis) (Sandground, 1932). The genus Cylicospirura has been documented in domestic and wild felids in India (Chandler, 1925), Italy (Ibba et al., 2014), southern Africa (Junker et al., 2013), North America (Crossland et al., 2015; Ferguson et al., 2011; Pence et al., 1978), and South America, including Brazil (Gallas et al., 2014; Vieira et al., 2017).

Adult nematodes are usually found in the gastric mucosa, attached to the fibrous tissue of nodules, which have a small orifice that communicates with the stomach lumen (Pence et al., 1978; Bowman et al., 2002) where it may compromise digestion and cause chronic vomiting due to gastric obstruction (Ferguson et al., 2011). Usually, infections by species of the genus Cylicospirura do not cause clinical signs (Ibba et al., 2014; Crossland et al., 2015), making clinical diagnosis difficult.

The life cycle of Cylicospirura sp. is not completely elucidated. However, arthropods, such as beetles, are believed to act as intermediate hosts, and vertebrates as pacas (Agouti paca) and armadillos (Dasypus novemcinctus), serve as paratenic hosts. The definitive host becomes infected by ingesting infected intermediate or paratenic hosts (Bowman et al., 2002; Ferguson et al., 2011; Crossland et al., 2015).

There is a paucity of published data concerning pathological and parasitological findings for this nematode in Brazil. Therefore, this study aimed to report the parasitological and pathological findings in a Puma concolor, which was naturally infected with Cylicospirura felineus.

\section{Materials and Methods}

\section{Case presentation and clinical history}

An adult male puma (P. concolor) was found in a garage in the city of Sabará, state of Minas Gerais (19०53' $11^{\prime \prime} S$, $43^{\circ} 48^{\prime} 24^{\prime \prime}$ W), Brazil. During the attempted capture, the animal was accidentally hit by a car and was immediately referred to a veterinary clinic, to receive appropriate treatment. Nevertheless, the animal died three days later. After death, a post mortem examination was performed at the Pathology Sector of the Veterinary School of the Universidade Federal de Minas Gerais (UFMG). The study was approved by the Ethics Committee for Animal Research of the UFMG under protocol 332/2013 and by the biodiversity information and authorization system (SISBIO) of the Instituto Chico Mendes de Conservação da Biodiversidade (ICMBio) under license 34633-5.

\section{Post mortem examination and parasite collection}

During post mortem examination, samples of the stomach mucosa with nodules, and all organs were collected and fixed in $10 \%$ buffered formalin for $48 \mathrm{~h}$. For histopathological examination, the samples were dehydrated in an increasing series of ethanol, diaphanized in xylol, embedded in paraffin to obtain $4 \mu \mathrm{m}$-thick serial sections, stained with hematoxylin and eosin, and examined under a common light microscope. Twenty-seven nematodes present in the gastric nodules were recovered, washed in $0.85 \%$ saline, and fixed in $10 \%$ neutral-buffered formalin at $80^{\circ} \mathrm{C}$ for morphological and morphometric analyses, as described by Avelar et al. (2013).

\section{Parasitological analysis}

From the 27 nematodes collected, nine (five males and four females) were cleared in Amann's lactophenol for morphological and morphometric identification. Measurements were made in millimeters (unless otherwise indicated). For each characteristics the interval was first provided, followed by the mean and coefficient of variation (between brackets). Images were captured using a digital camera attached to a white light microscope. Drawings were made at the Laboratory of Scientific Illustration of the Instituto de Ciências Biológicas (ICB) da UFMG. Some specimens were also prepared for conventional scanning electron microscopy (SEM) as previously described (Lopes et al., 2013) and analyzed at the Centro de Microscopia Eletrônica - UFMG. 


\section{Results}

\section{Gross and histopathology}

Macroscopically, the animal was in poor body condition, with marked anemia (pale mucous membranes, pale-red muscles and organs, low blood viscosity), and with numerous unidentified ticks. In the subcutaneous tissue and musculature of the lateral thoracic face, close to the vertebral column, some projectile fragments were found. The lungs were congested and edematous. In the gastric mucosa, approximately seven elevated and firm nodules, measuring $2.0 \times 1.0 \times 0.5 \mathrm{~cm}$ to $2.0 \times 1.5 \times 1.0 \mathrm{~cm}$, were found. These nodules were coated by an intact mucosa with a central opening from which reddish and cylindrical nematodes protruded into the lumen (Figure 1). On the cut surface, these nodules consisted of firm white septa, interspersed by slits containing cylindrical and reddish nematodes ranging from 1.5 to $2.0 \mathrm{~cm}$ in length, also visualized after fixed in formalin (Figure 2). In the liver, multiple whitish, multifocal to coalescent foci were also present in all lobes. Vehicle-collision associated lesions were multifocal axial and appendicular skin erosions and lacerations. Multiple hemorrhages were present in the meninges of the right brain and medulla oblongata. Other gross findings included right unilateral cryptorchidism, and osseous calluses in the $8^{\text {th }}$ left rib, and in the $12^{\text {th }}$ and $13^{\text {th }}$ right ribs.

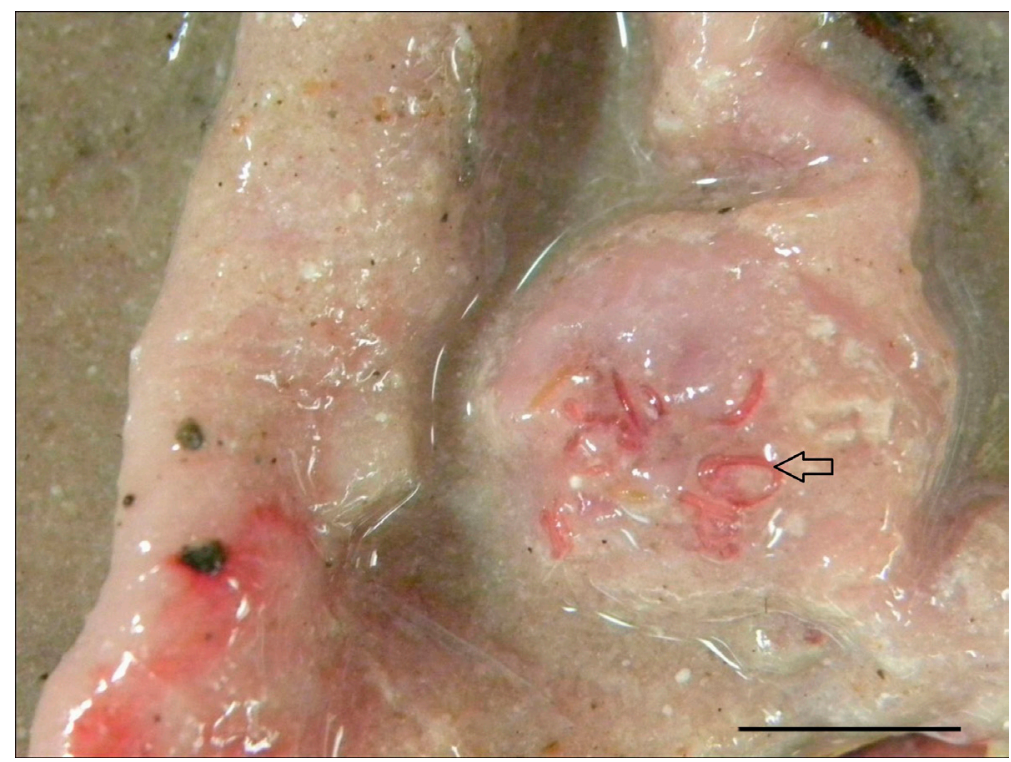

Figure 1. Macroscopic image of the stomach mucosa of a puma (Puma concolor) with a nodule. The nodule contains a central pore with multiple red nematodes (arrow) that protrude into the gastric lumen. Bar $=4 \mathrm{~cm}$.

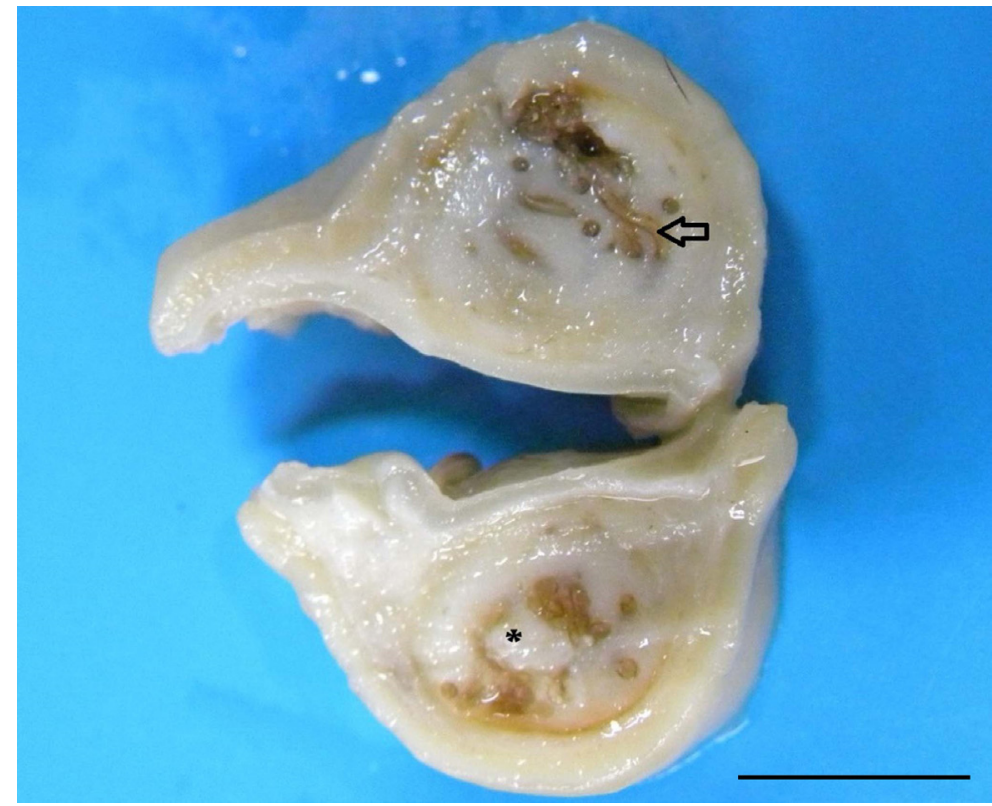

Figure 2. Longitudinal section of formalin-fixed gastric nodule shown in Figure 1. Nodular thickening of submucosa with anastomosing white tracts (asterisk) interspersed by pale brown nematodes (black arrow). Bar=4cm. 
In the histopathology, the gastric nodules were composed by an extensive proliferation of fibrous connective tissue, containing fibroblasts and thick bands of collagen interspersed by plasmacytes, macrophages, and neutrophils, which extended from the mucosa to the submucosa. The core of the nodule communicated with the gastric lumen via a pore or small ulcer through the mucosal layer. The adjacent mucosal epithelium had mucous cell hyperplasia. Thick bands of collagen (sclerosing fibroplasia) formed abundant interconnecting bands in multiple areas, surrounding adult nematodes in longitudinal and transverse sections ranging from $250 \mu \mathrm{m}$ (males) to $450 \mu \mathrm{m}$ (females) in diameter (Figure 3). Numerous macrophages contained vacuoles and granular brown pigment in the cytoplasm (hemosiderin). In addition, there were also necrosis, multifocal mineralization and areas with intact and degenerated eggs surrounded by epithelioid macrophages. The nematodes contained an eosinophilic cuticle, with caudally serrated projections (bulbar-like), coelomyarian musculature, and a pseudocoelom partially filled with amorphous eosinophilic material. The intestine was lined by a uninuclear high columnar epithelium with long and thin apical cytoplasmic projections. Females had gravid uteri filled with numerous embryonated thick-shelled eggs (Figure 4). Males were identified by the presence of testicles and had a smaller diameter than females. In the liver, there was centrilobular coagulative necrosis. The cryptorchid testicle was atrophic, characterized by degeneration of seminiferous tubules and azoospermia.

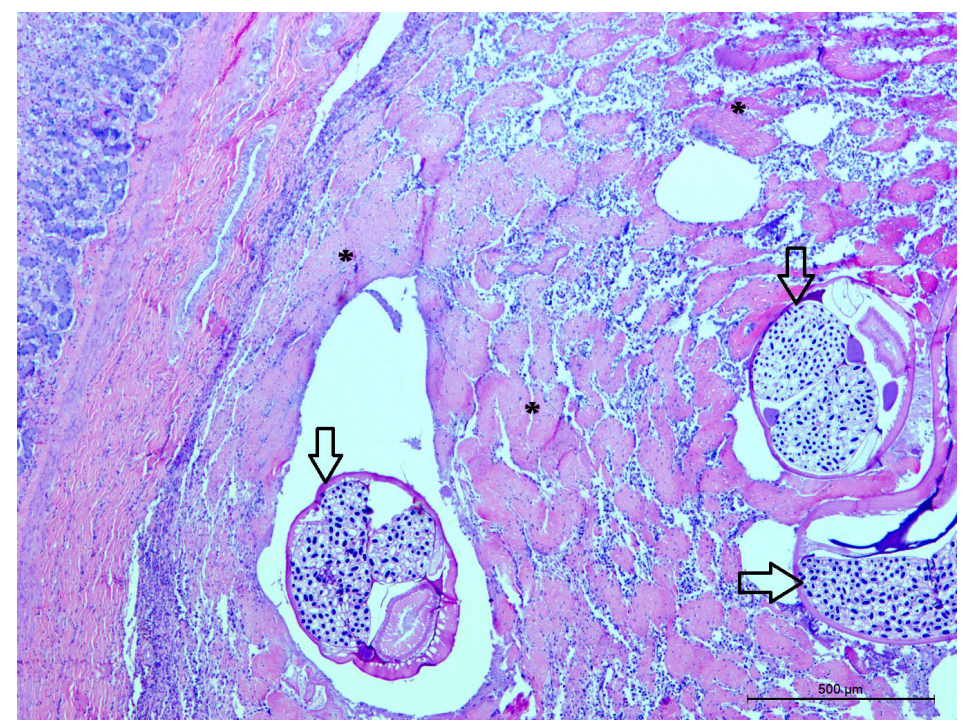

Figure 3. Photomicrography of the gastric nodule displayed in Figures 1 and 2 . The submucosa layer has multiple transverse sections of nematodes (arrow) surrounded by dense and anastomosed bands of sclerotic collagen (*) interspersed by inflammatory cells. Hematoxylin and eosin stain.

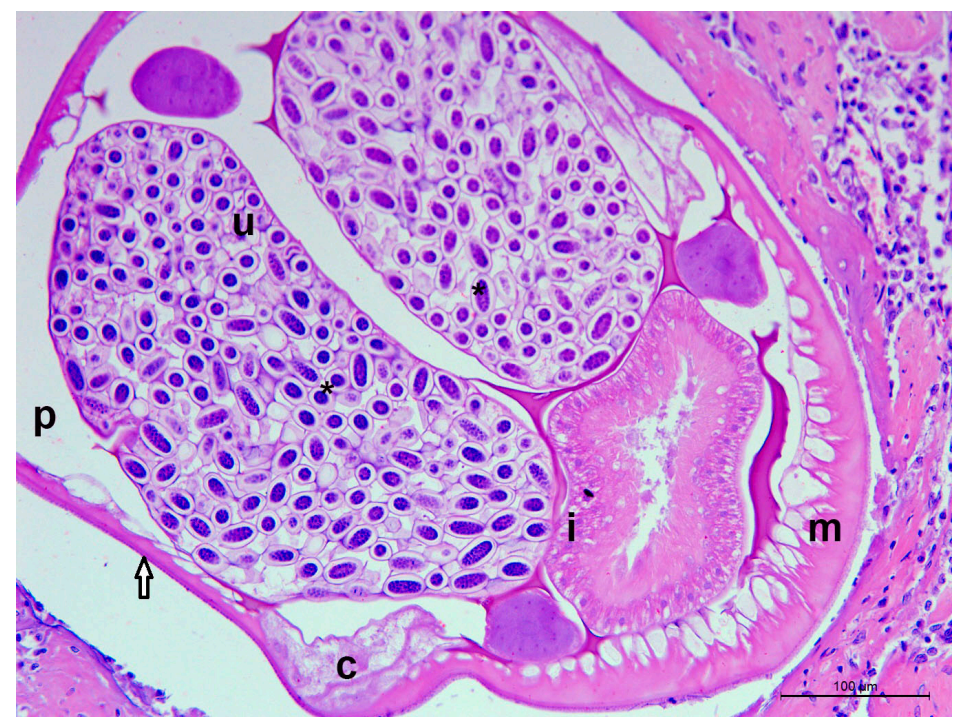

Figure 4. Photomicrography of a transverse section of a female nematode similar to that shown in Figure 3. The parasite is characterized by an eosinophilic thick cuticle (arrow); a coelomyarian musculature (m); a pseudocoelom (p); and intestine lined with uninucleate columnar epithelial cells (i), uterus (u) filled with numerous oval eggs (*), and lateral cords (c). Hematoxylin and eosin stain. 


\section{Parasitological description}

A total of 27 specimens, comprising 15 males and 12 females, were recovered from the gastric nodules.

General. (Figure 5a) Large, thick-bodied, reddish nematodes. Cuticle thick with transverse striations. Mouth with buccal capsule sclerotized with six large tricuspid teeth. Esophagus with anterior muscular and posterior glandular portions. Six small cephalic papillae.

Female. [based on four specimens; Figure 5a]: Length 20.45-23.99 (22.17 \pm 1.67$) \mathrm{mm}$. Maximum width 0.51-0.55 $(0.53 \pm 0.02) \mathrm{mm}$. Muscular and glandular esophagus 0.52-0.74 (0.63 \pm 0.09$) \mathrm{mm}$ long and 3.73-4.73 $(4.39 \pm 0.45) \mathrm{mm}$ long, respectively. Vulva opening anterior to esophagus-intestinal junction 2.1-4.06 (3.21 \pm 0.81$) \mathrm{mm}$ from anterior extremity. Tail blunt, short. Eggs thick-shelled, with well-developed larva 30.29-35.42 (33.5 \pm 1.84$) \mu \mathrm{m}$ long and 15.9-18.35 (16.74 \pm 0.78$) \mu \mathrm{m}$ wide.

Male. [Based on five specimens; Figures 5b, 5c, 6a, and 6b]: Length 16.18-19.16 (17.24 \pm 1.15$)$ mm. Maximum width $0.34-0.38(0.36 \pm 0.02) \mathrm{mm}$. Muscular and glandular esophagus $0.27-0.63(0.47 \pm 0.18) \mathrm{mm}$ long

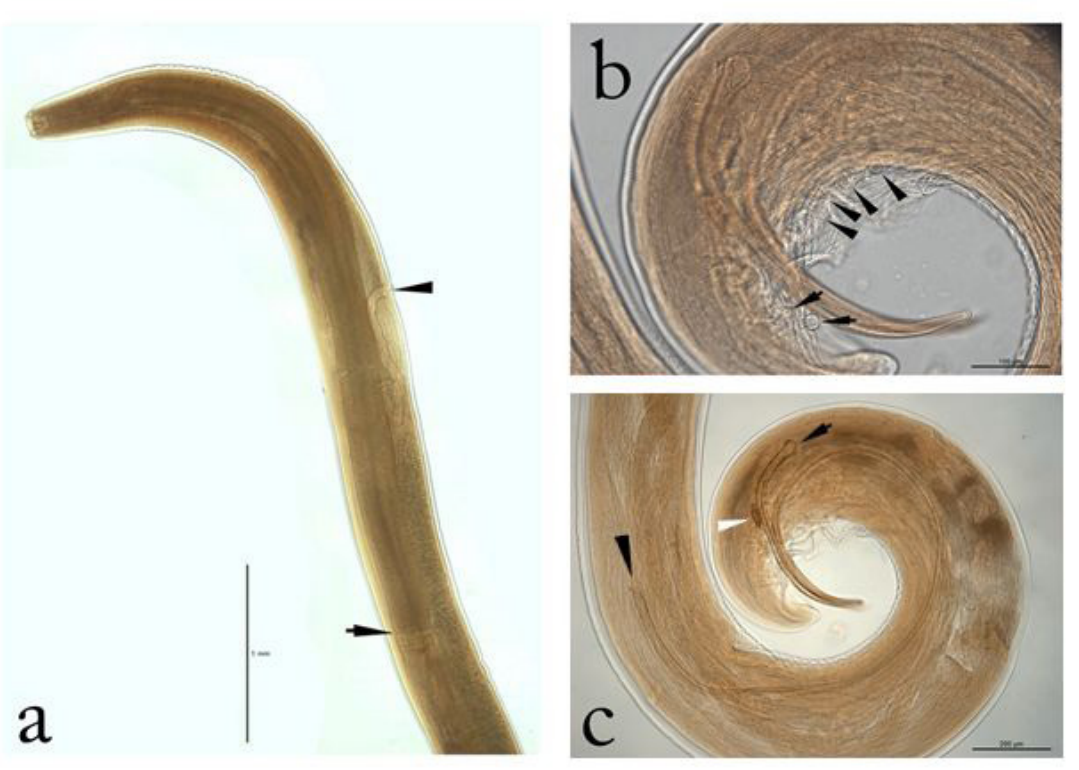

Figure 5. Adult specimen of Cylicospirura felineus. Anterior extremity of female showing the position of the vulva (arrowhead) opening anterior to esophagus-intestinal junction (arrow) (a). Lateral view of the posterior extremity of male showing six pedunculate caudal papillae: four preanal (arrowhead) and two postanal (arrow) (b). Lateral view of the posterior extremity of male in smaller increases, showing the largest spicule (arrowhead), the smallest spicule (arrow), and the gubernaculum (white arrowhead) (c).

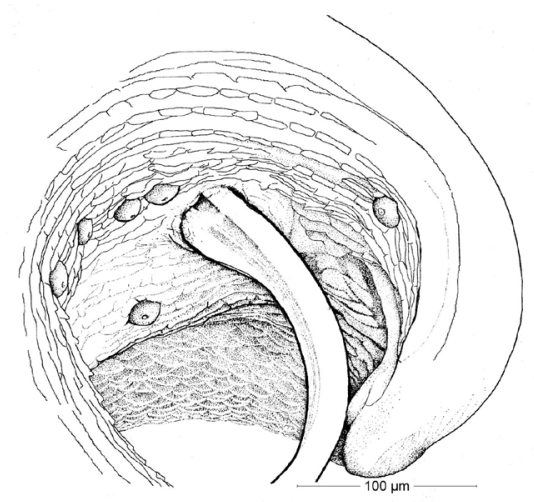

a

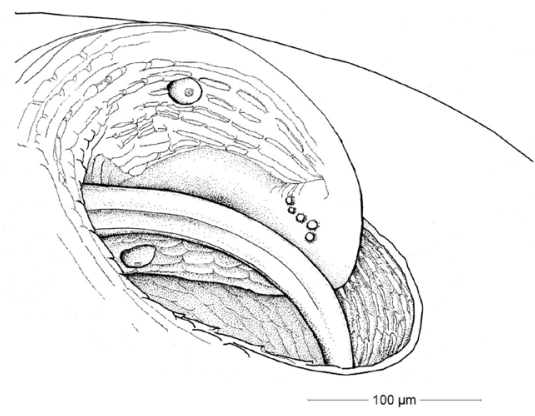

b

Figure 6. Drawings of the posterior extremity of a male of $C$. felineus, lateral view. Four preanal pedunculate caudal papillae on the right side, one on the left side and one postanal (a). A pair of post anal papillae, the projected spicules, and five small papillae near the tip of the tail (b). 


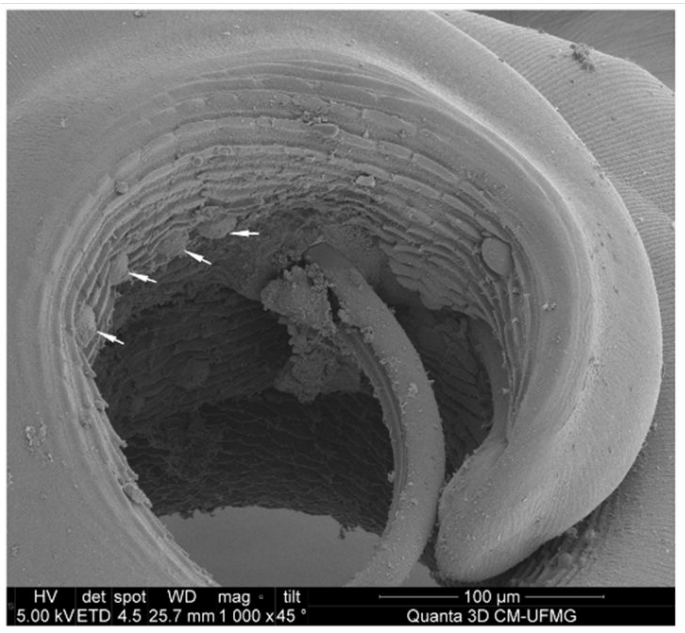

a

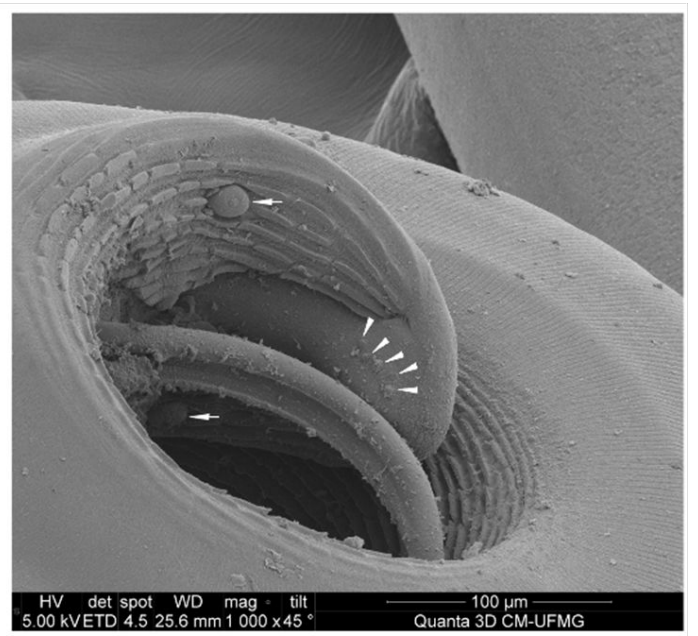

b

Figure 7. Scanning electron microscopy photomicrographs of $C$. felineus. Lateral view of the extremity of the male, showing in detail the four preanal papillae (white arrows) and projected spicules (a). The posterior extremity of the male, showing in detail one pair of postanal papillae (white arrows), the projected trough-shaped spicules, and five small papillae near the tip of the tail (arrowhead) (b).

and 2.87-3.54 (3.12 \pm 0.28$) \mathrm{mm}$ long, respectively. Spicules dissimilar: smallest measuring $0.48-0.66(0.56 \pm 0.075)$ $\mathrm{mm}$ with distal extremity blunt-tipped; largest measuring 2.26-2.60 $(2.42 \pm 0.15) \mathrm{mm}$. Gubernaculum sclerotized, $0.07-0.08(0.08 \pm 0.005) \mathrm{mm}$ long. Caudal alae present. Six pairs of large pedunculate caudal papillae: four pairs preanal and two pairs postanal. Five pairs of small papillae near tail tip. SEM results showed four pairs of preanal papillae (Figure 7a), one pair of postanal papillae, projected trough-shaped spicules, and five pairs of small papillae near tail tip (Figure $7 b$ ).

\section{Discussion}

The morphological and morphometric characteristics described in the present report for the Puma concolor parasites were consistent with Cylicospirura felineus, as described by Pence et al. (1978). In Brazil, the Cylicospirura felineus was first documented in Geoffroy's cat (Leopardus geoffroyi), from the state of Rio Grande do Sul (Gallas et al., 2014). A different species belonging to the same genus (Cylicospirura subaequalis) has been reported in pumas (P. concolor) and jaguarundi (Puma yagouaroundi) (Yamaguti, 1961; Vieira et al., 2017). This is the first report of Cylicospirura felineus infection in P. concolor in the state of Minas Gerais, Brazil.

Two species of Cylicospirura nematodes named C. felineus and C. subaequalis occur in the Americas and can be differentiated based on the presence of trifid or bifid teeth, respectively. In females, differentiation is made by the location of the vulva in relation to the anterior extremity and the esophageal junction with the intestine. In C. felineus, the vulva is located anterior to the esophagus - intestine junction, and in C. subaequalis, the vulva is located posterior to this junction. The males of both species can be characterized by the size of the spicules and the number of caudal papillae. C. felineus presents five caudal papillae and C. subaequalis presents four (Waid \& Pence, 1988). The morphological characteristics observed in the parasites evaluated in this report, allowed their identification as C. felineus.

In Brazil, the diet of $P$. concolor is mainly composed of capybaras (Hydrochoerus hydrochaeris), deer (Mazama gouazoubira and M. americana), peccaries (Pecari tajacu), pacas (Agouti paca), and armadillos (Dasypus novemcinctus) (Foster et al., 2010; Harmsen et al., 2011). However, smaller prey, such as small mammals, birds, reptiles, fish, and invertebrates are also consumed (Emmons, 1987; Rocha-Mendes et al., 2010). Stone \& Pence (1978) proposed that helminths of the Spiruroidea superfamily, such as C. felineus, can be transmitted by paratenic hosts, as strictly carnivorous felids are capable of acquiring the infection. Thus, pumas most likely become infected by ingesting invertebrates (intermediate hosts), or prey vertebrates, that have invertebrates in their dietary composition, and may act as paratenic hosts. 
Gastric cylicospiruriasis often represents an incidental finding in cats (Ibba et al., 2014; Crossland et al., 2015). In the present report, despite the lack of clinical data of the animal, post mortem examination showed a poor body condition and anemia. Centrilobular hepatic necrosis may be related to hypoxia resulting from anemia. This condition may have been caused by ectoparasitism and possibly contributed to the poor body condition of the animal. In addition, Ferguson et al. (2011) reported the possibility of infection with Cylicospirura sp. to be related to chronic vomiting, digestion impairment, diarrhea, weight loss, and severe host disease.

The histological changes in the puma of the present report with multiple random nodules in the stomach mucosa were similar to that described by others studies (Pence et al., 1978; Ferguson et al., 2011; Ibba et al., 2014; Crossland et al., 2015). A different location was reported in a wild lynx (Lynx rufus), which had pedunculated parasite-containing nodular lesions protruding from the serous layer of the pyloric region (Pence et al., 1978).

From the histopathology, the nodules in the submucosa are characterized by branched and anastomosed dense sclerotic collagen bands interspersed with inflammatory infiltrate, which expanded beyond the submucosa (Pence et al., 1978; Ferguson et al., 2011; Ibba et al., 2014; Crossland et al., 2015). In the present animal, dense collagen proliferation identified in the parasitic nodules was interpreted as sclerosing fibroplasia. These changes have been previously described in wild cats with Cylicospirura infection, and could be the result of the release of cytokines that stimulate collagen production during inflammation (Eckstrand et al., 2013). The lesions preceding the neoplastic transformation caused by Spirocerca lupi in the esophagus of dogs (Pence et al., 1978) are similar to those previously described in Cylicospirura infection. However, there are no reports of gastric neoplasia associated with infection by this parasite in felids (Ferguson et al., 2011).

Cylicospirura sp. in higher infection may be debilitating to the host, reducing its ability to hunt (Ferguson et al., 2011), which can accentuate conflicts between people and wild carnivores in areas with great anthropic pressure associated with prey scarcity. Thus, wild felids from anthropized areas that are admitted to institutions for treatment should be evaluated, and deworming should be discussed when cachexia, frequent vomiting (possibly associated with large nodules partially occluding the pyloric sphincter), and diarrhea are present. The detection of larvae or embryonated eggs in the stool samples can be an important diagnostic tool (Ibba et al., 2014). However, it is very important to take serial samples, to avoid false negatives due to fluctuations in the elimination of eggs by the parasites.

\section{Conclusion}

This is the first report of $C$. felineus parasitizing the stomach of $P$. concolor in the state of Minas Gerais, Brazil. This parasite should be included in the differential diagnosis of nodular gastric wall lesions in wild felids. More studies are necessary to further investigated the possible impacts of this infection on the health of wild felids.

\section{Acknowledgements}

The authors would like to thank Marco Anacleto (Scientific Illustration Laboratory, Instituto de Ciências Biológicas, Universidade Federal of Minas Gerais, Brazil) and the Centro de Microscopia Eletrônica - UFMG. We also would like to thank veterinarian Leonardo Maciel for referring the animal for necropsy and the Brazilian agencies members of the Centro Nacional de Pesquisas para Conservação dos Predadores Naturais (CENAP), the Instituto Brasileiro do Meio Ambiente e dos Recursos Naturais Renováveis (IBAMA), and the Instituto Estadual de Florestas (IEF) for providing licenses, samples, and supporting every step of our conservation efforts. The study received financial support from Research Support Foundation of the State of Minas Gerais (Fundação de Amparo à Pesquisa do Estado de Minas Gerais, FAPEMIG), WSL grant numbers 18898 and 0242413 . Fellowships were provided by the Conselho Nacional de Desenvolvimento Científico e Tecnológico, CNPq (WSL, grant number 480469/2012-1) and the Coordenação de aperfeiçoamento de Pessoal de Nível Superior - Brasil (CAPES) - Finance Code 001.

\section{References}

Avelar IO, Almeida LR, D'Elia ML, Santos HA, Soares DFM, Pereira PLL, et al. Pathological and parasitological findings in a Brazilian hoary fox (Lycalopex vetulus, Lund, 1842) infected by Oslerus osleri (Cobbold, 1876) (Nematoda: filaroididae). Braz J Vet Pathol 2013; 6(3): 111-115.

Bowman DD, Hendrix CM, Lindsay DS, Barr SC. Feline Clinical Parasitology. 1st ed. Ames, lowa: lowa State University Press; 2002. http://dx.doi.org/10.1002/9780470376805. 
Chandler AC. The helminthic parasites of cats in Calcutta and the relation of cats to human helminthic infections. Indian J Med Res 1925; 13(2): 213-228.

Conforti VA, Azevedo FCC. Local perceptions of jaguars (Panthera onca) and pumas (Puma concolor) in the Iguaçu National Park area, south Brazil. Biol Conserv 2003; 111(2): 215-221. http://dx.doi.org/10.1016/S0006-3207(02)00277-X.

Crossland NA, Hanks CR, Ferguson JA, Kent ML, Sanders JL, Del Piero F. First report of Cylicospirura felineus in a feral domestic shorthair cat in North America. JMFS Open Rep 2015; 1(2): 1-9. http://dx.doi.org/10.1177/2055116915593964. PMid:28491368.

Dotta G, Verdade LM. Medium to large-sized mammals in agricultural landscapes of south-eastern Brazil. Mammalia 2011; 75(4): 345-352. https://doi.org/10.1515/MAMM.2011.049.

Eckstrand CD, Barr BC, Woods LW, Spangler T, Murphy B. Nematode-associated intramural alimentary nodules in pumas are histologically similar to gastrointestinal eosinophilic sclerosing fibroplasias of domestic cats. J Comp Pathol 2013; 148(4): 405-409. http://dx.doi.org/10.1016/j.jcpa.2012.07.003. PMid:22925264.

Emmons LH. Comparative feeding ecology of felids in a Neotropical rainforest. Behav Ecol Sociobio/ 1987; 20(4): 271-283. http:// dx.doi.org/10.1007/BF00292180.

Ferguson JA, Woodberry K, Gillin CM, Jackson DH, Sanders JL, Madigan W, et al. Cylicospirura species (Nematoda: Spirocercidae) and stomach nodules in cougars (Puma concolor) and bobcats (Lynx rufus) in Oregon.J Wildl Dis 2011; 47(1): 140-153. http://dx.doi. org/10.7589/0090-3558-47.1.140. PMid:21270003.

Foster RJ, Harmsen BJ, Valdes B, Pomilla C, Doncaster CP. Food habits of sympatric jaguars and pumas across a gradient of human disturbance. J Zool (Lond) 2010; 280(3): 309-318. http://dx.doi.org/10.1111/j.1469-7998.2009.00663.x.

Gallas M, Silveira EF, Périco E. Cylicospirura (Cylicospirura) felineus (Chandler, 1925) Sandground, 1932 (Nematoda, Spirocercidae) in Leopardus geoffroyi D’orbigny \& Gervais, 1844 (Carnivora, Felidae): first report from the State of Rio Grande do Sul, Brazil. Neotrop Helminthol 2014; 8(2): 349-355.

Harmsen BJ, Foster RJ, Silver SC, Ostro LET, Doncaster CP. Jaguar and puma activity patterns in relation to their main prey. Mamm Biol 2011; 76(3): 320-324. http://dx.doi.org/10.1016/j.mambio.2010.08.007.

Ibba F, Lepri E, Veronesi F, Di Cesare A, Paltrinieri S. Gastric cylicospirurosis in a domestic cat from Italy. J Feline Med Surg 2014; 16(6): 522-526.

Junker K, Lane EP, McRee AE, Foggin C, van Dyk DS, Mutafchiev Y. Two new species of Cylicospirura Vevers, 1922 (Nematoda: Spirocercidae) from carnivores in southern Africa, with validation of the related genera Gastronodus Singh, 1934 and Skrjabinocercina Matschulsky, 1952. Folia Parasitol (Praha) 2013; 60(4): 339-352. https://doi.org/10.14411/fp.2013.035

Lopes EJT, Souza W, Miranda K. Comparative analysis of Trichuris muris surface using conventional, low vacuum, environmental and field emission scanning electron microscopy. Vet Parasito/ 2013; 196(3-4): 409-416. https://doi.org/10.1016/j.vetpar.2013.02.026

Pence DB, Samoil HP, Stone JE. Spirocercid stomach worms (Nematoda: Spirocercidae) from wild felids in North America. Can J Zool 1978; 56(5): 1032-1042. https://doi.org/10.1139/z78-146

Rocha-Mendes F, Mikich SB, Quadros J, Pedro WA. Feeding ecology of carnivores (Mammalia, Carnivora) in Atlantic Forest remnants, Southern Brazil. Biota Neotrop 2010; 10(4): 21-30. http://dx.doi.org/10.1590/S1676-06032010000400001.

Sandground JH. Report on the nematode parasites collected by the Kelley-Roosevelts expedition to Indo-China with descriptions of several new species. Part. I. Parasites of birds. Part II. Parasites of mammals. Z Parasitenkd 1932; 5(3-4): 542-583. http://dx.doi. org/10.1007/BF02121363.

Stone JE, Pence DB. Ecology of helminth parasitism in the bobcat from west Texas. J Parasitol 1978; 64(2): 295-302. http://dx.doi. org/10.2307/3279676. PMid:641672.

Treves A, Karanth KU. Human-Carnivore conflict and perspectives on Carnivore Management Worldwide. Conserv Bio/ 2003; 17(6): 1491-1499. https://doi.org/10.1111/j.1523-1739.2003.00059.x

Vickers TW, Sanchez JN, Johnson CK, Morrison SA, Botta R, Smith T, et al. Survival and mortality of Pumas (Puma concolor) in a fragmented, urbanizing landscape. PLoS ONE 2015; 10(7):1-18. https://dx.doi.org/10.1371\%2Fjournal.pone.0131490

Vieira FM, Muniz-Pereira LC, Souza-Lima S, Rocha BM, Luque JL. Parasitic nematodes of three species of wild carnivore mammals from Atlantic forest in the state of Minas Gerais, Brazil. Rev Mex Biodivers 2017; 88(4): 801-806. https://doi.org/10.1016/j.rmb.2017.10.033

Waid DD, Pence DB. Helminths of mountain lions (Felis concolor) from southwestern Texas, with a redescription of Cylicospirura subaequalis (Molin, 1860) Vevers, 1922. Can J Zool 1988; 66: 2110-2117. https://doi.org/10.1139/z88-313

Wainwright CJ, Darimont CT, Paquet PC. British Columbia's Neglected Carnivore: a conservation assessment and conservation planning guide for cougars. Version 01. Sidney, BC: Raincoast Conservation Foundation; 2010.

Yamaguti S. System Helminthum. Volume III. The nematodes of vertebrates. Parts I and II. New York: Interscience Publishers Inc; 1961. 